\title{
PENGARUH PROGRAM BELAJAR RADIO “FREE RADIO CLASS” TERHADAP PERSEPSI KHALAYAK DAN KEMAMPUAN BERBICARA DI DEPAN UMUM (SURVEI PADA PESERTA DI KOMUNITAS BELAJAR RADIO)
}

\author{
Mega Mercia Laraswati ${ }^{1}$, Siti Maryam², Priyono Sadjijo³ \\ ${ }^{1,2,3}$ Program Studi IImu Komunikasi, FISIP, Universitas Pembangunan Nasional Veteran Jakarta
}

Naskah diterima tanggal 01-10-2019, direvisi tanggal 02-11-2019, disetujui tanggal 20-01-2020

\begin{abstract}
Abstrak. Penelitian ini bertujuan untuk mengetahui seberapa besar pengaruh program Belajar Radio "Free Radio Class" terhadap persepsi khalayak dan kemampuan berbicara di depan umum. Teori yang yang relevan dalam penelitian ini adalah teori Self-Efficacy Bandura. Penelitian ini dilakukan dengan menggunakan pendekatan kuantitatif. Dengan metode survei. Populasi penelitian ini adalah peserta yang mengikuti program Belajar Radio "Free Radio Class" dengan jumlah sampel 90 responden. Teknik analisis pengaruh variabel $X$ terhadap variabel $Y$ menggunakan uji koefisien determinasi. Teknik pengujian data diproses menggunakan program SPSS (Statistical Product and Service Solution) versi 23. Hasil penelitian ini menunjukkan bahwa korelasi dan variabel pengaruh program "Free Radio Class" dengan variabel persepsi khalayak adalah sangat kuat dan pengaruh program "Free Radio Class" dengan variabel kemampuan berbicara adalah kuat. Berdasarkan hasil perhitungan koefisien determinasi diperoleh hasil adanya pengaruh variabel pengaruh program "Free Radio Class" terhadap variabel persepsi dan pengaruh program "Free Radio Class" terhadap kemampuan berbicara di depan umum diatas $50 \%$ artinya keduanya signifikan. Dengan demikian perhitungan pengaruh program "Free Radio Class" dengan persepsi khalayak dan perhitungan pengaruh program "Free Radio Class" dengan kemampuan berbicara di depan umum maka dapat disimpulkan $\mathrm{Ho} 1$ ditolak dan $\mathrm{Ha} 1$ diterima dan $\mathrm{Ho} 2$ ditolak dan $\mathrm{Ha} 2$ diterima yang berarti terdapat pengaruh yang signifikan antara program Belajar Radio "Free Radio Class" terhadap persepsi khalayak dan kemampuan berbicara di depan umum.
\end{abstract}

Kata Kunci: Program "Free Radio Class", Persepsi Khalayak, Kemampuan Berbicara di Depan Umum.

Abstract. This research aims to find out how big the influence of learning program of Radio "Free Radio Class" against the perception of the audience and the ability to speak in public. The relevant theories in this research is the theory of Self-Efficacy. The research was conducted using a quantitative approach. With the survey method. The population of this research is the participant who follow learning program Radio "Free Radio Class" with a total of 90 samples of respondents. The technique analysis of the influence of variables $X$ against $Y$ variables using the coefficient determination test. The technique of testing data is processed using program SPSS (Statistical Product and Service Solution) version 23. The results of this research show that correlation and variables influence the program "Free Radio Class" with variable perceptions of the audience is very strong and the influence of the program "Free Radio Class" with variable ability to talk is strong. Based on the results of the calculation of the coefficient of determination is obtained the results of the presence of the influence of variables influence the program "Free Radio Class" against the variable perception and influence program "Free Radio Class" against public speaking ability is above $50 \%$ it means both are significant. Thus the influence of the calculation program "Free Radio Class" with the perception of the audience and the calculation of the influence of the program "Free Radio Class" with the ability to speak in public then it can be inferred Ho1 rejected and accepted Ha1 and Ha2 rejected and Ho2 
accepted which means there is significant influence between the learning programs of Radio "Free Radio Class" against the perception of the audience and the ability to speak in public.

Keywords: "Free Radio Class" Program, Audience Perception, Public Speaking Ability.

\section{PENDAHULUAN}

Berbicara merupakan kemampuan yang dimiliki seseorang untuk menyampaikan gagasan, pikiran atau perasaan sehingga gagasan-gagasan yang ada dalam pikiran pembicara dapat dipahami orang lain. Berbicara berarti mengemukakan ide atau pesan lisan secara aktif melalui lambang-lambang bunyi agar terjadi kegiatan komunikasi antara penutur dan mitra tutur. Memang setiap orang dikodratkan untuk bisa berbicara atau berkomunikasi secara lisan, tetapi tidak semua memiliki keterampilan untuk berbicara secara baik dan benar.

Berbicara diartikan sebagai kemampuan mengucapkan bunyi-bunyi artikulasi atau katakata untuk mengekspresikan, menyatakan dan menyampaikan pikiran, gagasan, serta perasaan (Tarigan, 1983 hal:14). Dapat dikatakan bahwa berbicara merupakan suatu tandatanda yang dapat didengar (audible) dan yang kelihatan (visible) yang memanfaatkan sejumlah otot tubuh manusia demi maksud dan tujuan gagasan atau ide-ide yang dikombinasikan. Berbicara merupakan suatu bentuk perilaku manusia yang memanfaatkan faktor-faktor fisik, psikologis, neurologis, semantic, dan linguistik.

Survei yang dilakukan oleh The People's Almanac Book of list terhadap 3000 orang di Amerika mengenai hal yang paling mereka takutkan didalam hidup. Dan ternyata orang Amerika mayoritas lebih berani mati ketimbang Public Speaking kerena kematian berada diurutan ketujuh sementara Public Speakingmenempati urutan pertama, 630 orang atau sekitar $21 \%$ (urutan teratas) dari para responden mengatakan bahwa hal yang paling mereka takutkan adalah Public Speaking. Sedangkan berdasarkan survei yang dilakukan oleh Chapman University, di tahun 2016, ada sebanyak 25.9\% warga Amerika yang memiliki ketakutan terhadap Public Speaking.

Penelitian awal dilakukan peneliti pada kelas mahasiswa terutama pada mahasiswa jurusan IImu komunikasi. Pada mahasiswa jurusan IImu Komunikasi mahasiswa mendapatkan mata kuliah yang menunjang untuk tampil di depan umum, yaitu mata kuliah teori tentang keterampilan berbahasa dan berkomunikasi secara efektif pada mata kuliah nafas dan olah vokal serta praktek menjadi pembawa acara (master of ceremony), host, presenter TV dan penyiar radio (announcer), moderator, menjadi pembicara.

Mahasiswa mengemukakan pendapat tentang apa yang dialami ketika mendapatkan kesempatan berbicara di depan umum. Mereka mengungkapkan, bahwa ketika mendapat kesempatan tampil di depan umum, perasaan yang dialami adalah merasa takut, gemetar, grogi (demam panggung). Keringat dingin keluar, tangan terasa basah, merasakan lemas pada lutut, mengeluarkan keringat yang berlebih, jantung berdebar dengan kencang, mahasiswa berulang kali pergi ke toilet menjelang berbicara di depan umum dan mahasiswa berjalan mondar-mandir tanpa alasan saat menjelang berbicara di depan umum. Mereka juga mengungkapkan sudah berlatih berulang kali, tetapi ketika membaca naskah gemetar dan suara menjadi tidak terkontrol, masih sering gugup karena tidak percaya diri. Bahkan terkadang lupa apa yang akan disampaikan saat berbicara di depan umum.

Menurut (Rakhmat, 1998) Komunikasi dilakukan oleh tiap orang tak terkecuali dilakukan mahasiswa, komunikasi informal maupun formal. Komunikasi informal yang dilakukan mahasiswa adalah berbicara dengan teman atau orang yang ditemui, diskusi tentang materi perkuliahan maupun saat belajar kelompok. Komunikasi formal dilakukan mahasiswa dalam perkuliahan adalah saat presentasi tugas di depan kelas dan pada saat mahasiswa praktek berkomunikasi dengan orang lain. Mahasiswa juga diharapkan mampu dan berani mengemukakan pendapat dalam kegiatan formal maupun informal. Mahasiswa sering mengalami kekhawatiran sebelum melaksanakan presentasi, sehingga keluar keringat dingin, saat berbicara suara bergetar dan kurang lancar berbicara. Kemampuan untuk menciptakan komunikasi yang efektif menyebabkan individu yang terlibat dalam proses komunikasi merasa senang, sehingga mendorong tumbuhnya sikap saling terbuka. 
Keterampilan komunikasi merupakan salah satu kemampuan berbahasa dan berkomunikasi, yang perlu dimiliki oleh mahasiswa sebagai calon ilmuwan yang senantiasa bersentuhan dengan kegiatan yang menuntut mereka untuk terampil berbicara, seperti bertanya di dalam kelas, berdiskusi, berpidato, ceramah, dan lain-lain. Berbicara di depan publik seperti berpidato, berceramah, dan berdakwah dalam kehidupan manusia membutuhkan keterampilan dalam berkomunikasi. Banyak orang yang berhasil dalam hidupnya karena mempunyai kemampuan berbicara di depan publik, di samping kemampuan lain. Sebaliknya, banyak orang yang mempunyai ilmu dan banyak idenya, tidak tidak mempunyai keterampilan komunikasi.

\section{METODE PENELITIAN}

Penelitian ini menggunakan metode penelitian survei menggunakan kuesioner. Kuesioner dapat disebut juga sebagai instrumen survei yang berisikan daftar pertanyaan yang mengukur variabel, hubungan antara variabel-varibel yang ada (Prasetyo, Jannah, 2010, hal. 143). Jenis penelitian yang akanpeneliti gunakan adalah pendekatan kuantitatif eksplanatif. Metode analisis data pada penelitian ini adalah analisis korelasi Spearman, untuk dapat menentukan hubungan dua variabel yaitu Program "Free Radio Class" sebagai variabel X dan Persepsi Masyarakat sebagai variabel Y1, Kemampuan Berbicara di Depan Umum Y2 yang berskala ordinal (Siregar, 2013, hal. 380). Rumus korelasi Spearman (Siregar, 2013, hal. 380).

Teknik yang digunakan dalam proses penarikan sampel adalah non probability sampling, dan teknik penarikan sampel menggunakan jenis simple random sampling dengan cara dilakukan secara acak tanpa memperhatikan strata yang ada dalam populasi itu. Jumlah populasi yang dijadikan responden yaitu sebesar 850 orang. Hasil perhitungan menggunakan rumus slovin didapat jumlah responden yang akan dijadikan sampel yaitu berjumlah 90 responden.

Metode analisis data pada penelitian ini adalah analisis korelasi Spearman, untuk dapat menentukan hubungan dua variabel yaitu Program "Free Radio Class" sebagai variabel X dan Persepsi Masyarakat sebagai variabel Y1, Kemampuan Berbicara di Depan Umum Y2 yang berskala ordinal (Siregar, 2013, hal. 380). Rumus korelasi Spearman (Siregar, 2013, hal. 380). Uji korelasi dilakukan untuk mengetahui hubungan antara variabel $X$ (Terpaan Iklan) dengan variabel $Y$ (Perilaku Adiksi). Koefisien korelasi antara variabel $X$ dan $Y$ diolah menggunakan SPSS versi 23 dengan hasil sebagai berikut:

Tabel 1

Varibel $X$ dengan $Y 1$

\begin{tabular}{lrr}
\hline & Program Free Radio Class & Persepsi Khalayak \\
\hline Program Free Radio Class & 1.000 & $.800^{* *}$ \\
& 90 & .000 \\
& $900^{* *}$ & 90 \\
\hline Persepsi Khalayak & .000 & 1.000 \\
& 90 &. \\
\hline
\end{tabular}

Tabel 2

Varibel $\mathrm{X}$ dengan $\mathrm{Y} 2$

Program Free Radio Class Kemampuan bebicara di depan umum

\begin{tabular}{lrr}
\hline Program Free Radio Class & 1.000 & $.743^{* *}$ \\
& 90 & .000 \\
& 90 \\
\hline Kemampuan berbicara di depan & $.743^{* *}$ & 1.000 \\
umum & .000 &. \\
& 90 & 90 \\
\hline
\end{tabular}


Kemudian dilakukan analisis koefisien determinasi untuk mengetahui persentase pengaruh variabel independen terhadap variabel dependen dengan menggunakan uji korelasi. Rumus koefisen determinasi ialah sebagai berikut:

$$
\mathrm{Kd}=\mathrm{r}^{2} \times 100 \%
$$

Di mana:

$$
\begin{array}{ll}
\mathrm{Kd} & =\text { Koefisien determinasi } \\
r & =\text { Koefisien Korelasi }
\end{array}
$$

Maka $\mathrm{X}$ dengan $\mathrm{Y} 1$ :

$\mathrm{Kd}=0,704^{2} \times 100 \%$

$$
=0,640 \times 100 \%=64 \%
$$

Perhitungan diatas menunjukkan hasil dari determinasi nilai korelasi $(r)=0,800$ dan nilai $R$ square (hasil penguadratan nilai korelasi) $=0,640$ dengan hasil perhitungan total $=64 \%$.

Maka X dengan Y2:

$\mathrm{Kd} \quad=0,704^{2} \times 100 \%$

$=0,552 \times 100 \%=\mathbf{5 5 , 2} \%$

Perhitungan diatas menunjukkan hasil dari determinasi nilai korelasi $(r)=0,743$ dan nilai $R$ square (hasil penguadratan nilai korelasi) $=0,552$ dengan hasil perhitungan total $=55,2 \%$.

Uji hipotesis dilakukan untuk menguji signifikasi koefisien korelasi variabel $X$ (terpaan iklan) dengan variabel $Y$ (perilaku adiksi).

Rumus Uji t :

$$
t=r \frac{\sqrt{n-2}}{\sqrt{1-r^{2}}}
$$

Keterangan :

$\mathrm{t}=$ Uji Signifikasi

$r=$ Koefisiensi korelasi

$\mathrm{n}=$ Jumlah responden $(\mathrm{n}-2=\mathrm{dk}$, derajat kebebasan)

Variabel $\mathrm{X}$ dengan $\mathrm{Y} 1$

$$
\begin{gathered}
t=\frac{0,800 \sqrt{90-2}}{\sqrt{1-0,800}} \\
t=\frac{0,800 \sqrt{88}}{\sqrt{1-0,640}} \\
t=\frac{0,800 \sqrt{88}}{\sqrt{1-0,640}} \\
t=\frac{0,800 \times 9,380}{\sqrt{36}} \\
t=\frac{7,504}{0,6} \\
t=12,506
\end{gathered}
$$


1. Jika t hitung $>\mathrm{t}$ tabel, maka $\mathrm{H} 01$ ditolak dan $\mathrm{Ha} 1$ diterima (ada pengaruh)

2. Jika t hitung < t tabel, maka Ha1 diterima dan H01 diterima (tidak ada pengaruh)

Kesimpulan hasil dengan cara membandingkan $t$ hitung dengan $t$ tabel yang telah diperoleh dari proses perhitungan diatas. Penentuan level of signification $t$ tabel nilainya ditentukan pada taraf signifikansi 0,5 dengan $\mathrm{df}=\mathrm{n}-2=90-2=88$, maka diperoleh $\mathrm{t}$ tabel $=1,662$. Hasil $\mathrm{t}$ hitung berdasarkan tabel hasil perhitungan manual adalah sebesar 12,506.

Variabel $\mathrm{X}$ dengan $\mathrm{Y} 2$

$$
\begin{gathered}
t=\frac{0,743 \sqrt{90-2}}{\sqrt{1-0,743^{2}}} \\
t=\frac{0,743 \sqrt{88}}{\sqrt{1-0,552}} \\
t=\frac{0,743 \sqrt{88}}{\sqrt{1-0,552}} \\
t=\frac{0,743 \times 9,380}{\sqrt{0,448}} \\
t=\frac{6,969}{0,669} \\
t=10,417
\end{gathered}
$$

1. Jika t hitung $>\mathrm{t}$ tabel, maka $\mathrm{H} 02$ ditolak dan $\mathrm{Ha} 2$ diterima (ada pengaruh)

2. Jika $t$ hitung $<\mathrm{t}$ tabel, maka Ha2 diterima dan $\mathrm{H} 02$ diterima (tidak ada pengaruh)

Kesimpulan hasil ditentukan dengan cara membandingkan $t$ hitung dengan $t$ tabel yang telah diperoleh dari proses perhitungan diatas. Penentuan level of signification $t$ tabel nilainya ditentukan pada taraf signifikansi 0,5 dengan $\mathrm{df}=\mathrm{n}-2=90-2=88$, maka diperoleh $\mathrm{t}$ tabel $=$ 1,662. Hasil t hitung berdasarkan tabel hasil perhitungan manual adalah sebesar 10,417.

\section{SIMPULAN}

Hubungan antara program "Free Radio Class" dengan persepsi khalayak menunjukkan nilai korelasi $r$ sebesar 0,800 pada analisis koefisien korelasi dengan kategori "sangat kuat" dan program "Free Radio Class" dengan kemampuan berbicara di depan umum menunjukkan nilai korelasi $r$ sebesar 0,743 pada analisis koefisien korelasi dengan kategori "kuat" sehingga dapat disimpulkan bahwa ketiga variabel memiliki hubungan yang kuat. Besaran kontribusi antara program "Free Radio Class'terhadap persepsi khalayak ini ditunjukkan oleh nilai pada hasil analisis koefisien determinasi dengan angka sebesar $64 \%$, sehingga dapat disimpulkan bahwa variabel X (program "Free Radio Class") pada penelitian ini memengaruhi variabel Y1 (persepsi khalayak) sebanyak $64 \%$ dan sisanya (34\%) dipengaruhi oleh faktor lain yang tidak disertakan dalam penelitian ini dan Besaran kontribusi antara program "Free Radio Class"terhadap kemampuan berbicara di depan umum ini ditunjukkan oleh nilai pada hasil analisis koefisien determinasi dengan angka sebesar $55,2 \%$, sehingga dapat disimpulkan bahwa variabel $X$ (program "Free Radio Class") pada penelitian ini memengaruhi variabel Y2 (kemampuan berbicara di depan umum) sebanyak $55,2 \%$ dan sisanya $(44,8 \%)$ dipengaruhi oleh faktor lain yang tidak disertakan dalam penelitian ini. Hasil yang telah diperoleh dari proses perhitungan diatas. Penentuan level of signification $t$ tabel nilainya ditentukan pada taraf signifikansi 0,5 dengan $\mathrm{df}=\mathrm{n}-2=90-2=88$, maka diperoleh $\mathrm{t}$ tabel $=1,662$. Hasil $\mathrm{t}$ hitung $\mathrm{X}$ dengan $\mathrm{Y} 1$ berdasarkan hasil perhitungan manual adalah sebesar 12,506 dan penentuan level of 
signification $\mathrm{t}$ tabel nilainya ditentukan pada taraf signifikansi 0,5 dengan $\mathrm{df}=\mathrm{n}-2=90-2=88$, maka diperoleh $t$ tabel $=1,662$. Hasil $t$ hitung $X$ dengan $Y 2$ berdasarkan hasil perhitungan manual adalah sebesar 10,417.

\section{DAFTAR PUSTAKA}

Bandura, A. 1986, Social foundation of Thought and Action: A Social Cognitive Teory. Prentice Hall, Englewood Cliffs, NJ.

Bandura, A. 1997, Self-Efficacy. The Exercise of Control. US, New York. Jalaludin, Rakhmat. (1998). Psikologi Komunikasi. Bandung: Rosda Jalaludin, Rakhmat, Psikologi Komunikasi. Cetakan Kedua Puluh Enam, Remaja Rosda Karya, Bandung.

Kriyantono, Rachmat. (2012). “Teknik Praktis Riset Komunikasi Cetakan ke-6”. Jakarta:

Kencana Prenada Media Group.

Nelson, R. dan Jones.2012, Pengantar Keterampilan Konseling. Introduction to Counseling Skills, Pustaka Pelajar, Yogyakarta.

Siregar, Syofian. 2013. Metode Penelitian Kuantitatif. Jakarta: PT Fajar Interpratama Mandiri. Sugiyono.2012, Metode Penelitian Pendidikan.Pendekatan Kuantitatif Kualitatif dan R \& D, ALFABETA, Bandung.

Sujianto, AE. 2009. Aplikasi Statistik Dengan SPSS.Jakarta : Prestasi Pustaka. Tarigan HG.1983 .Berbicara.Bandung :Angkasa

Rismayanti \& Rolina. 2004. "Pencarian Jati diri Melalui Proses Belajar dan Pengalaman". SPS-UGM (Tidak Diterbitkan). Yogyakarta.

Hall, dkk. 2002. "Teori-teori Sifat dan Behavioristik" dalam "Psikologi Kepribadian 3 (Editor Dr. A. Supratiknya)”. Cetakan ke-10 (Terjemahan).Kanisius. Yogyakarta. 